\title{
28. QUATERNARY FISH OTOLITHS FROM SITES 242 AND 246-LEG 25, DEEP SEA DRILLING PROJECT
}

\author{
Erlend Martini, Geologisch-Paläontologisches Institut der Universität, \\ Frankfurt am Main, Germany
}

\section{INTRODUCTION}

During foraminiferal studies (Zobel, this volume), fish otoliths have been found in Core 1 at Site 242 (latitude $15^{\circ} 50.65^{\prime} \mathrm{S}$, longitude $41^{\circ} 49.23^{\prime} \mathrm{E}$, Mozambique Channel, water depth $2275 \mathrm{~m}$ ) and Core 1 at Site 246 (latitude $33^{\circ} 37.21^{\prime} \mathrm{S}$, longitude $45^{\circ} 09.60^{\prime} \mathrm{E}$, Madagascar Ridge, water depth $1030 \mathrm{~m}$ ). Most of the otoliths are badly worn, but some are fairly well preserved and can be identified as to their genus.

The sample at Site 242 (Core 1, Section 2, 12-14 cm) which yielded the fish otoliths is a gray foraminifera-rich nannoplankton ooze. The other sample in which otoliths were encountered is from Site 246 (Sample 1, CC) and was identified as sand-size foraminiferal ooze with minor nanno foram ooze present. Both samples can be placed into standard nannoplankton Zone NN21 (Emiliania huxleyi Zone) and into Zone N.23 (Globigerina calida calidal Sphaeroidinella dehiscens excavata Zone) of the planktonic foraminiferal zonation, indicating that the age of the samples is Recent to late Pleistocene.

All specimens, with the probable exception of a few very badly worn otoliths, belong to the lantern fish family (Myctophidae). Due to poor preservation of most specimens, species identification is not attempted.

\section{SYSTEMATIC DESCRIPTION}

\section{Family MYCTOPHIDAE Gill, 1892 \\ Genus DIAPHUS Eigenmann, 1891 \\ Diaphus sp.}

(Plate 1, Figures 3-6; Plate 2, Figures 7, 8, 11-14)

Six sagittae are assigned to the genus Diaphus, two from Site 242 and four from Site 246. The two specimens from Site 242 are nearly oval shaped with a worn spinose ventral margin and show a distinct rostrum and a small antirostrum. The excisura in both cases is small and the sulcus prominent, the ostium being larger than the cauda. The outer faces show distinct radiating grooves. One sagitta (Plate 1, Figures 3,4) is very similar to Diaphus garmani Gilbert, 1906, showing a small but distinct excisura, whereas the other one (Plate 1 , Figures 5,6 ) which has a less distinct excisura may represent Diaphus splendidus (Brauer, 1904). Two of the four Diaphus sagittae from Site 246 (Plate 2, Figures 7, 8, 13, 14) seem to represent Diaphus brachycephalus Taning, 1928, which also is relatively high compared with the length, shows a distinct rostrum and antirostrum, and has a more or less smooth outer face with slight grooves only near the margins. The other two specimens are too worn for comparison with a certain species of the genus Diaphus, but show the general appearance of this genus. The specimen shown in Plate 2, Figures 11, 12 does not show the spinose ventral margin and is provisionally assigned to this genus.
Genus HYGOPHUM Tåning, 1932

Hygophum sp.

(Plate 3, Figures 3, 4)

Two specimens were encountered at Site 246 , one of which is badly worn and does not allow specific identification. The other sagitta (Plate 3, Figures 3,4) is one of the largest specimens in the present collection of otoliths. The height is slightly greater than the length, rostrum and antirostrum are large, and the sulcus is almost straight. The ventral margin shows some undulation and lacks a marked postventral corner. The postdorsal part is large and reaches beyond the line of the postventral part. It is very similar and may be identical with Hygophum macrochir (Günther, 1864).

\section{Genus LAMPANYCTUS Bonaparte, 1840}

Lampanyctus sp.

(Plate 1, Figures 13, 14; Plate 2, Figures 1-6)

Four otoliths are assigned to the genus Lampanyctus, one sagitta from Site 242 and three sagittae from Site 246 . The sagitta from Site 242 (Plate 1, Figures 13, 14) is distinctly smaller than those from Site 246, has a shorter antirostrum, and lacks the compact appearance which is shown by the sagittae from Site 246 (Plate 2, Figures 1-6). The sulcus is not a channel and seems to be straight with the ostium slightly larger than the cauda. One sagitta (Plate 2, Figures 5,6$)$ shows close similarity to Lampanyctus alatus Goode and Bean, 1896, although the angle of the area between the rostrum and antirostrum is larger in the specimen in Kotthaus, $1972 \mathrm{~b}$ (pl. 2, fig. 15) but matches the one in Kotthaus, 1972a (fig. 83). The other two sagittae from Site 246 (Plate 2, Figures 1-4) may represent adult stages of Lampanyctus intricarius Tåning, 1928 (compare Kotthaus, 1972b, fig. 14), as the antirostrum is of about the same length as the rostrum or is slightly longer, and the area between both shows a distinct incision.

Genus MYCTOPHUM Rafinesque, 1810

Myctophum sp.

(Plate 1, Figures 7-10)

Two sagittae from Site 242 belong to the genus Myctophum. As no comparable material from the Indian Ocean is available, specific identification is not attempted. One specimen is small (Plate 1, Figures 7,8 ) and shows radiating grooves on the outer face. Rostrum and antirostrum are well developed with a distinct excisura between both. The ventral margin is undulate in the anterior two-thirds. There is some similarity to sagittae of Myctophum asperum Richardson from the western North Atlantic. The other sagitta (Plate 1, Figures 9, 10) is somewhat elongated with a truncate posterior end. The antirostrum is small and high, about two-thirds or more of the distance between ventral and dorsal margins. The margins are smooth. It may be related to Myctophum punctatum Rafinesque from the western North Atlantic, which differs from the figured sagitta in having a more rounded posterior end. Two sagittae from Site 246 are badly worn and are provisionally assigned to the genus Myctophum. Because they do not show details which may be important for species identification, they are not figured. 
Genus NOTOSCOPELUS Günther, 1884

Notoscopelus sp.

(Plate 3, Figures 1, 2)

One sagitta found at Site 246 seems to represent a species of the genus Notoscopelus, although a species identification is not possible due to the bad stage of preservation. The sagitta found is much longer than high with an index of approximately length:height = 1.55. The rostrum is not very prominent, which also is the case with the antirostrum. The dorsal margin is smooth, whereas the ventral margin probably was undulated or spinose. The posterior part is somewhat rectangular in outline. The faintly visible sulcus seems to be straight with a slight inclination towards the postventral corner.

\section{Genus SYMBOLOPHORUS Bolin and Wisner, 1959}

Symbolophorus sp.

(Plate 1, Figures 1, 2, 11, 12; Plate 2, Figures 9, 10)

Three sagittae are assigned to this genus, two from Site 242 and a questionable one from Site 246. The largest one (Plate 1, Figures 1,2 ) is oval shaped and seems to represent an adult stage, as the margins are relatively smooth, which is not the case on juveniles. The rostrum is prominent whereas an antirostrum is only faintly indicated. The sulcus is large with an ostium nearly twice as long as the cauda. The better preserved sagitta from Site 242 (Plate 1, Figures 11, 12) is high compared with the length and shows radiating grooves on the outer face resulting in undulating ventral and dorsal margins. The rostrum is large, but an antirostrum is not developed. The ostium is straight and larger than the cauda, which "opens" towards the posterior end, showing similarity to the cauda of Symbolophorus rufinus (Tåning, 1928) as in Kotthaus (1972b, pl. 2, fig. 10). The third specimen, found at Site 246 , is badly worn, especially on the inner face, and is therefore assigned to this genus with some reservation, although the outline fits Symbolophorus (compare Figure 1). It has a distinct postdorsal corner, a prominent rostrum, and a small excisura below a poorly developed antirostrum. On the outer face radiating grooves are visible, indicating a subadult specimen.

Unidentifiable Otoliths

(Plate 1, Figures 15, 16; Plate 2, Figure 15)

Five otoliths could not be identified due to their poor preservation, most of which were from Site 246. The inner faces, especially, show signs of heavy corrosion and solution as discussed below. One specimen shown in Plate 2, Figure 15 has superficial similarity to worn otoliths of the Pterothrissidae, but lacks the grooves on the outer face, and also the sulcus seems not to extend to the margin.

\section{DISCUSSION}

The otolith associations at Sites 242 (Mozambique Channel) and 246 (Madagascar Ridge) are very similar and show only minor differences. Both associations are dominated by or consist solely of otoliths of the bathypelagic lantern fish family (Myctophidae), if one does not consider the unidentifiable otoliths. Otoliths of the genera Hygophum and Notoscopelus occur only at Site 246, but this may possibly be attributed to the relatively small number of otoliths found (Table 1).

At many localities (Sicily, Japan, California) of different ages, lantern fish otoliths are frequently associated with nonbathypelagic fish otoliths, indicating near-shore deposits with bathypelagic areas nearby. At both sites under consideration no identifiable otoliths of other fish families have been found, suggesting pelagic conditions for Sites 242 and 246.

The preservation of the otoliths of Site 242 is better than that of Site 246 due to the gray foraminifera-rich nannoplankton ooze in which the otoliths of Site 242 were found. The otoliths of Site 246, on the other hand, are in most cases badly worn; some otoliths are iron stained, and several specimens show solution effects (especially on the inner faces whereas the outer faces are only slightly worn), indicating long exposure at the surface and a slow sedimentation rate on the Madagascar Ridge. The difference in preservation of the inner and outer face of the otoliths may have resulted from the structure of the sulcus area. Stereoscan pictures of selected surface areas of a sagitta of the recent lantern fish Symbolophorus californiensis (Eigenmann and Eigenmann) from off the California coast (Figure 1a) show marked differences in the fine structure within and outside the sulcus. Within the sulcus, the surface is built of somewhat irregular assembled carbonate particles which are loosely connected and show a meshwork structure (Figure 1b), whereas areas outside the sulcus have a more compact structure (Figure 1c). Solution will affect the sulcus area much more than the other areas, for example, the outer face of the sagittae will resist more than
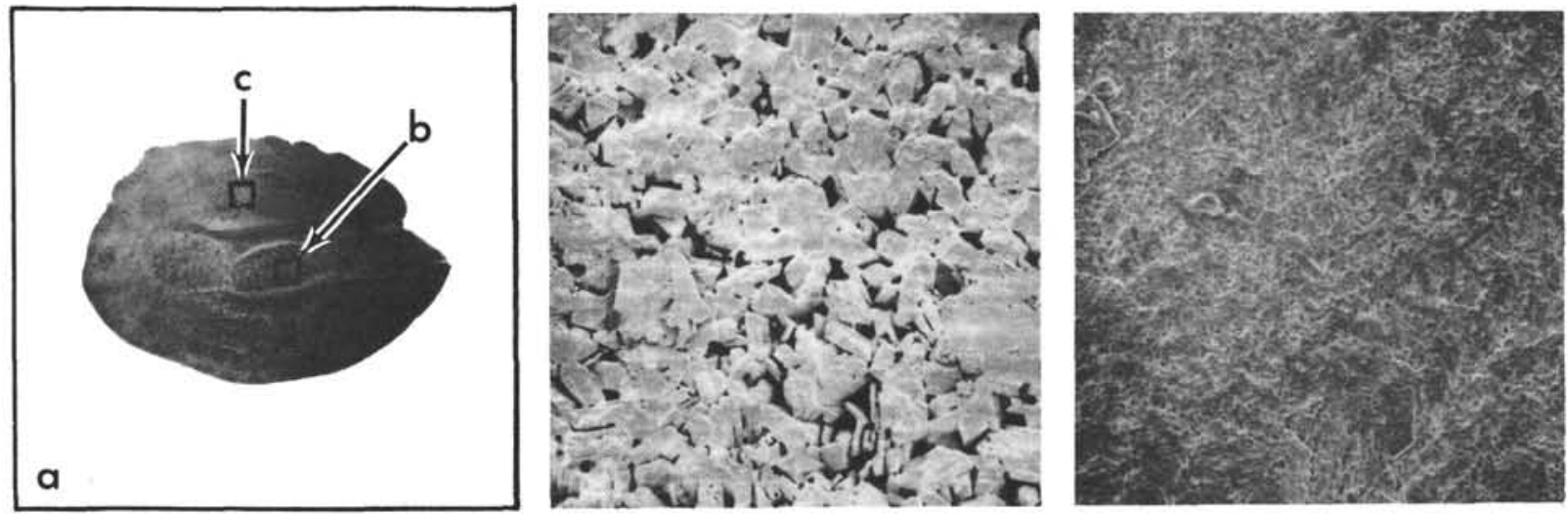

Figure 1. Symbolophorus californiensis (Eigenmann and Eigenmann) Recent, Pacific Ocean, off California. (a) Inner face of left sagitta, SEM, X 18. (b) Surface of area within the sulcus as indicated in figure 1a, SEM, X 900. (c) Surface of an area above the upper crest as indicated in figure 1a, SEM, X 900. 
TABLE 1

Fish Otoliths in Samples 242-1-2, 12-14 cm and 246-1, CC

\begin{tabular}{lcc}
\multicolumn{1}{c}{ Fossil } & Site 242 & Site 246 \\
\hline Diaphus sp. & 2 & 4 \\
Hygophum sp. & - & 2 \\
Lampanyctus sp. & 1 & 3 \\
Myctophum sp. & 2 & 2 \\
Notoscopelus sp. & - & 1 \\
Symbolophorus sp. & 2 & 1 \\
Myctophidae & - & 2 \\
Unidentifiable & 1 & 4 \\
Total number of specimens & 8 & 19 \\
\hline
\end{tabular}

the inner face, as is the case with most otoliths from Site 246. In this connection, two otoliths of lantern fishes are of special interest. The inner face of one sagitta (Plate 3, Figure 5) is badly destroyed by boring algae, and on the outer face of the other sagitta a sessil foraminifera of the genus Tolypammina (Plate 3, Figures 6,7) has settled. Both suggest exposure on the sea bottom for a certain period of time.

\section{ACKNOWLEDGMENTS}

Thanks are due to John E. Fitch (California State Fisheries Laboratory, Long Beach, California) and C. Müller (Geologisch-Paläontologisches Institut der Universität, Frankfurt a.M., Germany) for valuable help and discussions. A. Kotthaus (Biologische Anstalt, Helgoland, Germany) provided rare literature and a series of yet unpublished photographs of otoliths of members of the genus Diaphus from the Indian Ocean for comparison, and B. Zobel (Bundesanstalt für Bodenforschung, Hannover, Germany) provided the otoliths on which the study is based. H. Funk (Geologisch-Paläontologisches Institut der Universität, Frankfurt a.M.) made the excellent photographs of the otoliths. Figure 1a-c was made by J. Tochtenhagen with a Stereoscan Mark 2 provided to the GeologischPaläontologisches Institut by the VW-Stiftung.

\section{REFERENCES}

Kotthaus, A., 1972a. Die meso- und bathypelagischen Fische der "Meteor"-Rossbreiten-Expedition 1970 (2. und 3, Fahrtabschnitt); "Meteor"Forsch.-Ergeb., Reihe D, v.,11, p. 1-28.

1972b, Fische des Indischen Ozeans. Ergebnisse der ichthyologischen Untersuchungen während der Expedition des Forschungsschiffes "Meteor" in den Indischen Ozean, Oktober 1964 bis Mai 1965. A, Systematischer Teil. IX Iniomi (Nachtrag: Fam. Myctophidae): "Meteor"-Forsch.-Ergeb., Reihe D, v., 12, p. 12-35. 


\section{PLATE 1}

All specimens approximately $\times 30$, from Sample 242-1-2,

$12-14 \mathrm{~cm}$, late Pleistocene to Recent.

Figures 1, 2 Symbolophorus sp., left sagitta.

1. Inner face.

2. Outer face.

Figures 3, 4 Diaphus sp. cf. D. garmani Gilbert, 1906, left sagitta.

3. Inner face.

4. Outer face.

Figures 5, 6 Diaphus sp. cf. D. splendidus (Brauer, 1904), right sagitta.

5. Outer face.

6. Inner face.

Figures 7, 8 Myctophum sp., right sagitta.

7. Inner face.

8. Outer face.

Figures 9, 10 Myctophum sp., right sagitta.
9. Outer face.
10. Inner face.

Figures 11, 12 Symbolophorus sp., right sagitta.

11. Outer face.

12. Inner face.

Figures 13, 14 Lampanyctus sp., left sagitta.

13. Inner face.

14. Outer face.

Figures 15, 16 Not identifiable, left sagitta.

15. Inner face.

16. Outer face. 


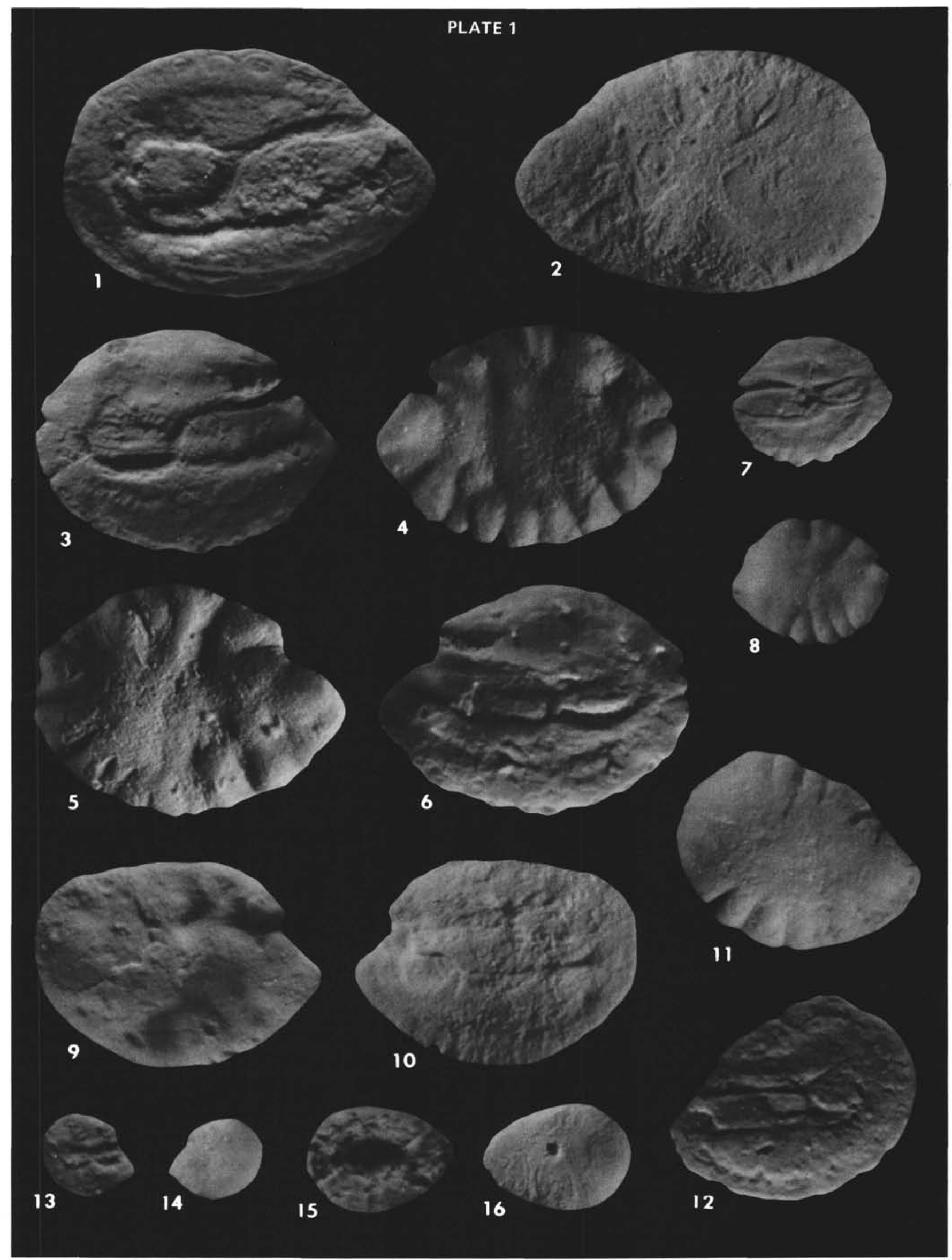




\section{PLATE 2}

All specimens approximately $\times 30$, from Sample 246-1, CC, late Pleistocene to Recent.

Figures 1, 2 Lampanyctus sp. cf. L. intricarius Tånig, 1928, left sagitta.

1. Inner face.

2. Outer face.

Figures 3, $4 \quad$ Lampanyctus sp. cf. L. intricarius Tåning, 1928, left sagitta.

3. Inner face.

4. Outer face.

Figures 5, 6 Lampanyctus sp. cf. L. alatus Goode and Bean, 1896, right sagitta.

5. Outer face.

6. Inner face.

Figures 7, 8 Diaphus sp. cf. D. brachycephalus Tåning, 1928, left sagitta.

7. Inner face.

8. Outer face.

Figures 9,10 Symbolophorus sp. ?, left sagitta.

9. Inner face.

10. Outer face.

Figures 11, 12 Diaphus sp. ?, right sagitta.

11. Outer face.

12. Inner face.

Figures 13,14 Diaphus sp.cf.D. brachycephalus Tåning, 1928, right sagitta.

13. Outer face.

14. Inner face.

Figure 15 Not identified, left sagitta, inner face. 

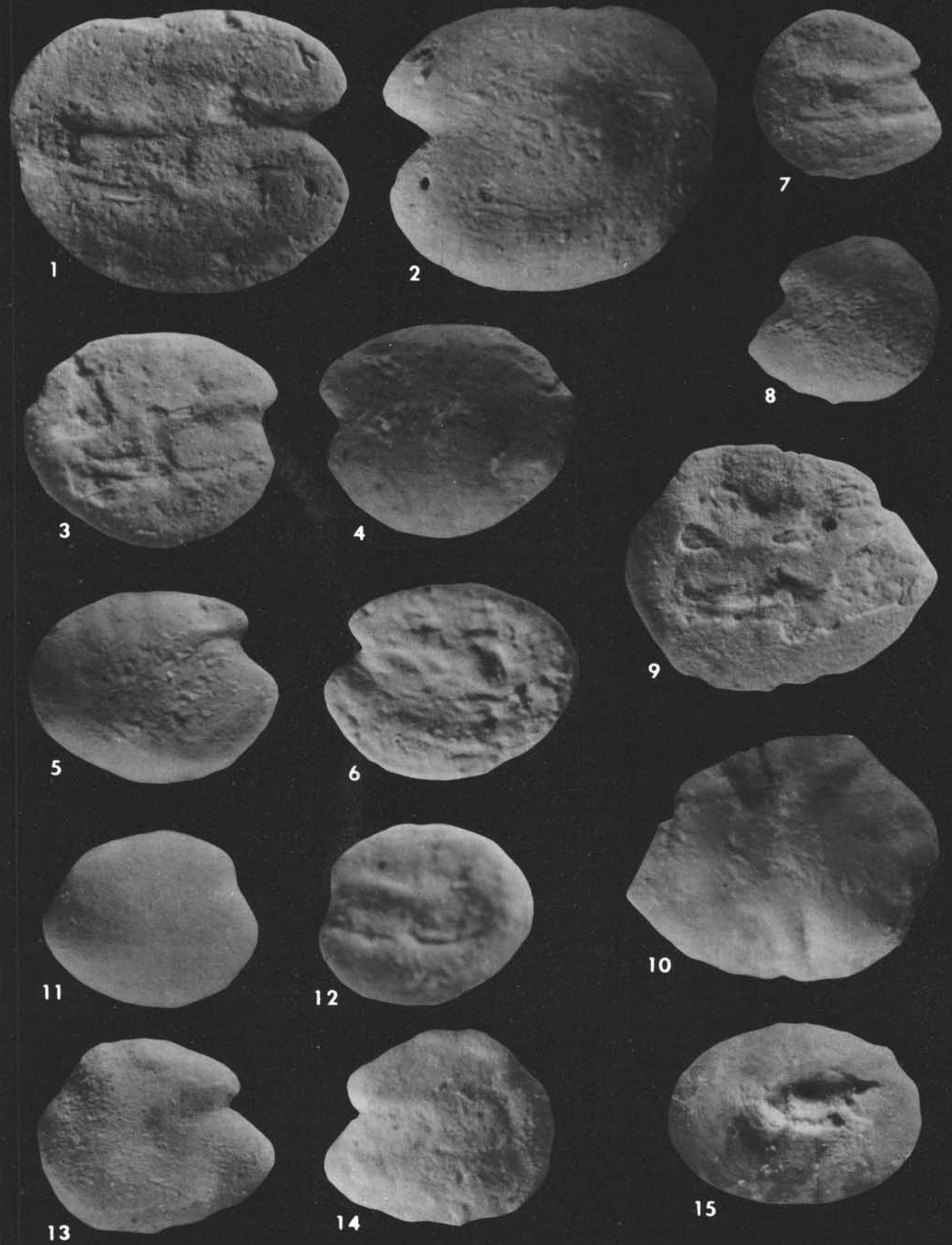
PLATE 3

All specimens approximately $\times 30$, from Sample 246-1, CC, late Pleistocene to Recent.

Figures 1,2 Notoscopelus sp., left sagitta.

1. Inner face.

2. Outer face.

Figures 3, 4 Hygophum sp. cf. H. macrochir (Günther, 1864), right sagitta.

3. Outer face.

4. Inner face.

Figure 5 Myctophidae, inner face of right sagitta, badly destroyed by boring algae.

Figures 6,7 Myctophidae, outer face of worn left sagitta, with sessil foraminifera Tolypammina. Two different illuminations. 


\section{PLATE 3}
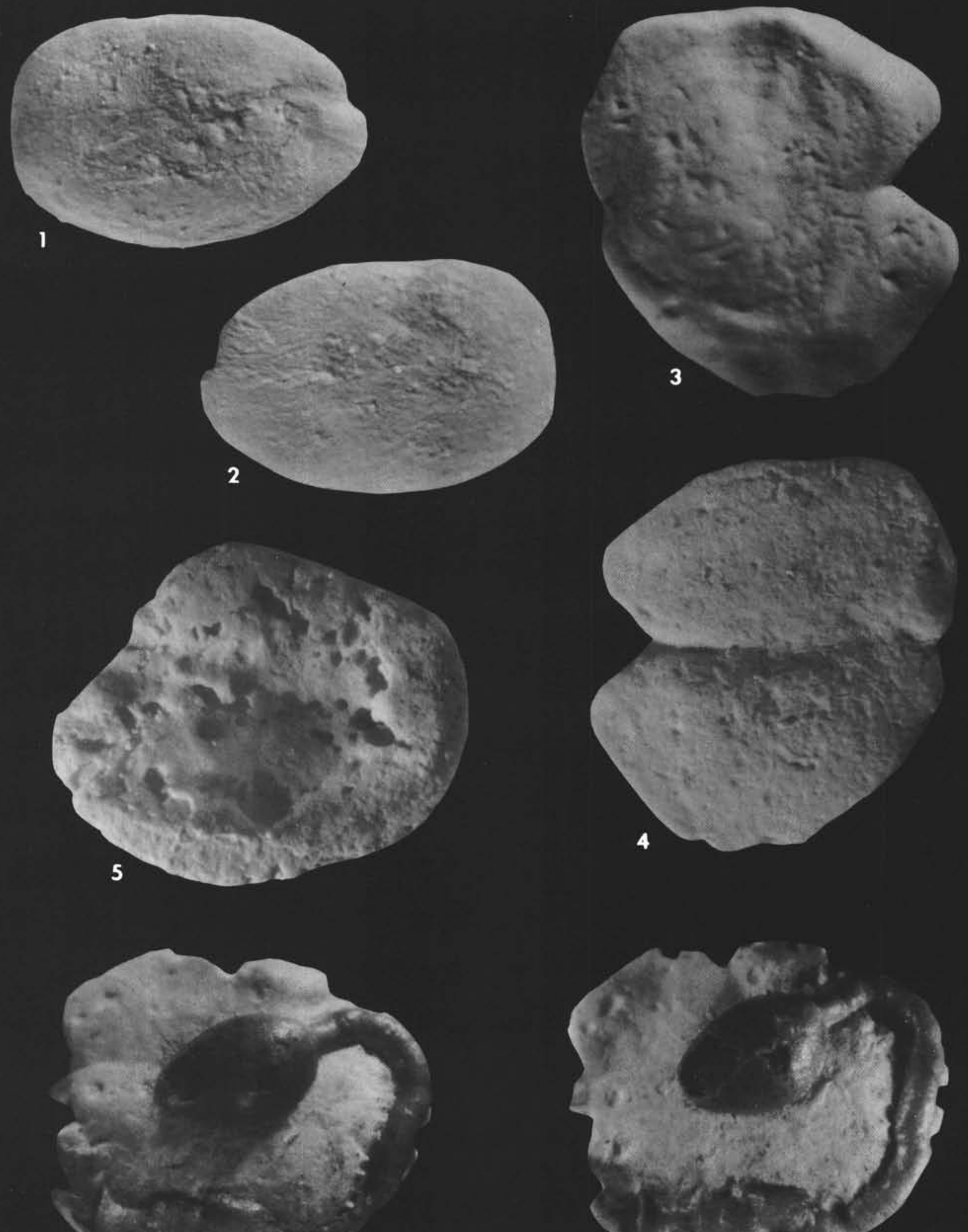

6

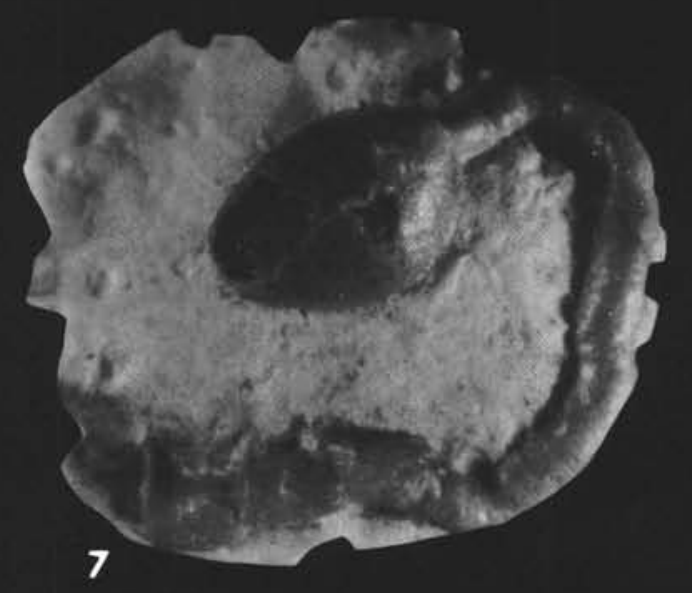

